\title{
Effect on Growth of Clarias gariepinus Post Fingerlings, Fed Graded Levels of Ocimum gratissimum as Feed Additive
}

\author{
Marroh Eseoghene \& Ekelemu Jerimoth Kesena \\ Department of Fisheries \\ Delta State University, Asaba Campus, Asaba-Nigeria \\ jerimothekelemu@yahoo.com
}

\begin{abstract}
Studies on the optimum inclusion level of Ocimum gratissimum (scent leaf) to the diet of Clarias gariepinus post-fingerlings on its growth and development was studied 16wks using 15 out-door tarpaulin tanks of dimension $1 \mathrm{~m} \times \mathrm{Im} \times \mathrm{Im}$. Tanks were grouped into five (5) treatments in triplicates (Tla-c to T5a-c). Treatment Tla-c is the control. Three hundred (300) post-fingerlings of Clarias gariepinus used were randomly distributed in twenties into each of the tanks. Fishes in the tanks were fed 2.0mm coppens at 3\% body weight two times daily. Treatments T2-T4 were respectively fed diets containing $10 \mathrm{~g}, 20 \mathrm{~g}, 30 \mathrm{~g}$, 40g of ground O. gratissimum per Kg of feed. Treatment $\mathrm{Tl}$ had no O. gratissimum inclusion. Length and weight of fish samples were measured fortnightly and used as growth parameters. Data collected were subjected to one-way analysis of variance and means were separated using Duncans multiple range test. The result obtained revealed that an increase in the inclusion level of $\mathrm{O}$. gratissimum, beyond $10 \mathrm{~g} \mathrm{per} \mathrm{Kg}$ of feed results in a decline in growth rate of fish. Optimum fish survival rate was also obtained in treatment 2. It is therefore concluded that the optimum inclusive level of $O$. gratissimum to achieve maximum growth is $10 \mathrm{~g} / \mathrm{kg}$ of feed.
\end{abstract}

Keywords: Ocimum gratissimum, Clarias gariepinus, growth.

\section{INTRODUCTION}

One of the basic necessities of life is food, second only to air and water. Fish like poultry and livestock is an animal protein food source. In Nigeria, fish consumption is higher due to its availability, ease of digestion and comparatively cheaper prices relative to that of farm reared animals (FAO, 2003). Due to increase in demand for fish and dwindling supply from the wild, fish culture has been accepted the world over as a means of increasing supply to meet the short fall. In a developing country like Nigeria aquaculture holds much promise because of its numerous water resources (Dada et al, 1983).

The expansion of fish culture has been a slow process because entrepreneurs in the sector face major challenges such as unavailability of seed and quality feed. Catfish family Clariidae is very popular in Nigeria due to its culture characteristics, which has endeared it to many fish farmers (FAO, 2004). Due to its high economic value, ability to survive in unsuitable habitats mostly due dissolved oxygen and fast growth rate, Clarias gariepinus is widely cultured and thus has high importance in aquaculture in Nigeria (Oladosu et al, 1993). In Nigeria, Medicinal plants have contributed greatly to healthcare. This could be attributed to the recognition of the value of trado-medical systems, and the recognition of plants from indigenous pharmacopoeias that are medicinal, which have important healing powers (John et al, 2000). In folk medicine, members of the lamiaceae have been used for a long time compared to other families of the plant kingdom.

Ocimim gratissimum has been known to provide various properties for both culinary and medicinal purposes. These properties trigger bacteriostatic effects on some bacteria. These bacteriostatic effects have been linked to the alkanoids, phenols, essential oils, peptides and flavonols, which are large properties of these plants (Okigbo and Igwe, 2007).

Ocimum oil is also effective against several strains of bacterias such as (Listeriamonocytogenes, Staphylococcus aureus, Escherichia coli) and fungi like (Candida albicans ,Penicillium islandicum (Akinyemi et al 2004; Lemos et al 2005; Lopez, 2005).

Antibiotics and their effects on animal products and the resistance to it by some bacteria especially the multi-drug resistant food-borne salmonella and clostridia infections, have caused a decline in the acceptance of the additive in some countries of the world. 
The antibiotics used as growth promoters for farm livestock has been restricted and banned by the European commission and Scandinavian countries (Plail, 2005). Ocimum gratissimum has been researched on and is been used as a natural anti-biotic because of its anti-bacterial and anti-fungal properties. Thus this study seeks to ascertain the use of $O$. gratissimum as a feed additive in place of the traditional antibiotics in fish feed.

\section{Materials AND Methods}

\subsection{Experimental Site}

This study was conducted in the teaching and research farm of the Department of Fisheries, Delta State University, Asaba in Oshimili South Local Government Area of Delta State Nigeria. Asaba is located in longitude $6.1978 \mathrm{oE}$ and latitude $6.7285 \mathrm{oN}$, of the equator. Asaba is situated along the River Niger.

\subsection{Preparation of Experimental Leaf Meal}

Fresh leaves of Ocimum gratissimum were collected, rinsed with clean water to remove any foreign matter, chopped and air-dried. The dried leaf of O. gratissimum was analyzed in the laboratory to ascertain their phytochemical content, using standard method (A.O.A.C. 1990). The dried leaves were milled using a hammer mill. The ground $O$. gratissimum was then thoroughly mixed with $2 \mathrm{~mm}$ coppens fish feed at a proportion of $0 \mathrm{~g}, 10 \mathrm{~g}, 20 \mathrm{~g}, 30 \mathrm{~g}$, and $40 \mathrm{~g}$ per $1 \mathrm{~kg}$ of feed and labeled as diets D1 to D5 respectively. Diet D1 which contained no O.gratissimum was the control.

\subsection{Experimental Design}

The experimental design was a complete randomized block design (CRBD). A total of 300 postfingerlings of Clarias gariepinus were used for this study. They were acclimated for 5 days during which time they were fed ad-libitum with coppens, morning and evening before the commencement of the experiment. Experimental fish were later distributed in twenties into fifteen (15) outdoor Tarpaulin tanks measuring $1 \mathrm{~m} \times 1 \mathrm{~m} \times 1 \mathrm{~m}$. The tanks containing fish, were randomly grouped in triplicates to form five (5) treatments T1a-c to T5a-c. Each treatment was fed diets with its corresponding number.

\subsection{Data Collection}

Body weight $(\mathrm{g})$ and standard length $(\mathrm{cm})$ of fish were respectively measured using an analytical weighing balance and a calibrated meter rule and recorded before the commencement of the experiment. Measurement of body weight and total length were conducted fortnightly throughout the sixteen (16) weeks of the study.

\subsection{Determination of Fish Growth and Performance}

The growth parameters were determined data collected on length and weight

Mean weight gain $(\mathrm{MWG})(\mathrm{g})=$ Final mean weight - Initial mean weight

Mean length gain $(M L G)(\mathrm{cm})=$ Final mean length - Initial mean length

Specific grown rate $(\mathrm{SGR})=(\ln \mathrm{Wf}-\ln \mathrm{Wi}) / \mathrm{t} \times 100$

Where, $\mathrm{Wf}=$ Final mean weight,

$\mathrm{Wi}=$ Initial mean weight,

$\mathrm{t}=$ Culture period in days

Survival rate $(\mathrm{SR})(\%)=$ No $\times 100 / \mathrm{Ni}$

$\mathrm{Ni}=$ Number of fish stocked at start of experiment

No $=$ Number of fish alive at end of experiment

Feed conversion ratio $(\mathrm{FCR})=$ Total food taken $(\mathrm{g}) /$ Total weight gain $(\mathrm{g}) \mathrm{X} 100$

Condition factor $(\mathrm{k})=\mathrm{W} \times 100 / \mathrm{L}^{3}$.

\subsection{Statistical Analysis}

Data collected were analyzed using Analysis of Variance (ANOVA) while the means were separated using the New Duncan Multiple Range Test (NDMRT) 
Effect on Growth of Clarias gariepinus Post Fingerlings, Fed Graded Levels of Ocimum gratissimum as Feed Additive

\section{RESUlts}

\subsection{Summary of Analysis of Variance for Growth Response in the Five Treatment Tanks}

\begin{tabular}{|l|l|l|l|l|l|}
\hline \multicolumn{7}{|c|}{ TREATMENTS } \\
\hline PARAMETERS & \multicolumn{1}{|c|}{$0 \mathrm{~g}(\mathrm{~T} 1)$} & \multicolumn{1}{|c|}{$10 \mathrm{~g}(\mathrm{~T} 2)$} & \multicolumn{1}{c|}{$20 \mathrm{~g}(\mathrm{~T} 3)$} & \multicolumn{1}{c|}{$30 \mathrm{~g}(\mathrm{~T} 4)$} & $40 \mathrm{~g}(\mathrm{~T})$ \\
\hline Weight & $174.98 \pm 1.00^{\mathrm{b}}$ & $181.06 \pm 1.34^{\mathrm{a}}$ & $144.79 \pm 1.08$ & $137.89 \pm 1.43^{\mathrm{d}}$ & $124.41 \pm 0.91^{\mathrm{e}}$ \\
\hline Length & $28.53 \pm 0.90^{\mathrm{b}}$ & $31.51 \pm 0.56^{\mathrm{a}}$ & $25.72 \pm 0.81^{\mathrm{c}}$ & $23.98 \pm 0.14^{\mathrm{d}}$ & $22.73 \pm 0.19^{\mathrm{d}}$ \\
\hline M.W.G & $47.61 \pm 1.21^{\mathrm{a}}$ & $44.19 \pm 1.11^{\mathrm{a}}$ & $33.11 \pm 1.27^{\mathrm{b}}$ & $31.79 \pm 0.38^{\mathrm{b}}$ & $21.35 \pm 1.56^{\mathrm{c}}$ \\
\hline M.L.G & $1.88 \pm 0.08^{\mathrm{ab}}$ & $1.93 . \pm 0.29^{\mathrm{a}}$ & $1.90 \pm 0.32^{\mathrm{a}}$ & $1.14 \pm 0.24^{\mathrm{c}}$ & $1.67 \pm 0.08^{\mathrm{b}}$ \\
\hline S.G.R. & $0.98 \pm 0.03^{\mathrm{a}}$ & $0.87 \pm 0.03^{\mathrm{ab}}$ & $0.81 \pm 0.03^{\mathrm{b}}$ & $0.81 \pm 0.01^{\mathrm{b}}$ & $0.58 \underline{ \pm 0.04}^{\mathrm{b}}$ \\
\hline F.C.R. & $8.75 \pm 0.05^{\mathrm{b}}$ & $9.05 \pm 0.07^{\mathrm{a}}$ & $7.24 \pm 0.06^{\mathrm{c}}$ & $6.89 \pm 0.07^{\mathrm{d}}$ & $6.22 \pm 0.05^{\mathrm{e}}$ \\
\hline C.F. (K) & $0.75 \pm 0.04$ & $0.58 \pm 0.02$ & $0.85 \pm 0.05$ & $1.00 \pm 0.03$ & $1.06 \pm 0.02$ \\
\hline S.R & $17.33 \pm 0.33^{\mathrm{a}}$ & $17.33 \pm 0.33^{\mathrm{a}}$ & $15.67 \pm 0.33^{\mathrm{b}}$ & $15.67 \pm 0.33^{\mathrm{b}}$ & $14.33 \pm 0.33^{\mathrm{c}}$ \\
\hline
\end{tabular}

Means with the same superscript on the same row are not significantly different $(P>0.05)$. Where; $\pm=$ standard error of the mean, $M W G=$ mean weight gain, $M L G=$ mean length gain, $S G R=$ specific growth rate, $S R=$ survival rate. $K=$ Condition factor.

The above table shows that Treatment 2 had the highest weight values of $181.06 \pm 1.34 \mathrm{~g}$, highest length values of $31.51 \pm 0.56 \mathrm{~cm}$, highest mean length gain value of $1.93 \pm 0.29 \mathrm{~cm}$, highest values of feed conversion ratio of $9.05 \pm 0.07 \%$, the least values for condition factor(k) of 0.58 and highest value of $17.33 \pm 0.33 \%$ for survival rate. Treatment 1 had the highest mean weight gain with value of $47.61 \pm 1.21 \mathrm{~g}$, highest specific growth rate with value of $0.93 \pm 0.03 \%$.The survival rate in Table 1 shows that treatment 1 and 2 has the highest value of $17.33 \pm 0.33 \%$.

\section{DisCUSSION}

In this study, it is observed that there is a significant increase in weight of fish in treatment 2 (T2), fed $10 \mathrm{~g}$ inclusion of Ocimum gratissimum compared to other treatments. This result is supported by Abbas et al., (2005), who reported that the gradual rise in replacement level of fish meal by sunflower meal affected the performance of major carps adversely in their growth and the lowest decrease in fish production was recorded at $25 \%$ replacement level while the highest decrease was recorded at $75 \%$ replacing level of fish meal by sunflower meal.

Ali et al, (2003); reported varying nutrient levels to affect growth responses of fish in their studies on tilapia using alfalfa as test feedstuff meal in the diet. They recorded a fall in growth performance which was said to be linearly correlated with level of alfalfa meal in the diet

Inferior growth response was observed for fish fed cassava based diet as compared to the control with zero cassava peel (Oresegun and Alegbeleye, 2001; Anyanwu, et al 2012). Olvera-Novoa et al.,(2002) also showed that replacing animal protein source in Tilapia fry diets with sunflower seed meal up to $20 \%$ was possible with significant increase in body weight of Nile Tilapia fry while the highest replacement levels significantly decreases the body weight.

In this study, it is observed that there was a significant increase in length of fish in treatment 2 (T2), fed $10 \mathrm{~g}$ inclusion of O.gratissimum compared to other treatments. There was a significant increase in SGR of T1 $(0 \mathrm{~g})$ when compared with other treatments. SGR values seen in this study were supported with that reported by Erfanullah and Jafri (1998), Alegbeleye et al, (2001) and Ochang et al, (2007), Who acknowledged that SGR of Clarias gariepinus post fingerlings fed control diet were significantly higher $(\mathrm{P}<0.05)$ than those fed on diets containing leaf meals.

The trend in $S G R$ of the experimental fish in this study might be an indication of their responses to the varied dietary inclusion levels of $O$. gratissimum leaf meal.

In this study, T2 $(10 \mathrm{~g})$ had the highest FCR values. The trend in the FCR of C. gariepinus, with significant decrease $(\mathrm{P}<0.05)$ at levels above $10 \mathrm{~g}$, as observed for $20 \mathrm{~g}, 30 \mathrm{~g}$ and $40 \mathrm{~g}$ OGLM dietary inclusion.

This is an indication of the good attributes of the leaf meal in supporting growth and nutrient utilization in C. gariepinus at limited quantities. OGLM contains $12-18 \%$ crude protein and had been shown to contain anti-nutritional substances, particularly safrole which inhibits digestion of cell walls in ruminants because of their antimicrobial activity, thereby reducing productivity (Ilori et al, 1996; Junaid et al, 2006). (Ugwuoke et al 2014). 
Anyanwu et al, (2008) reported that SGR and FCR of post fingerlings fed control diet were significantly higher $(\mathrm{P}<0.05)$, than those fed on leaf meals at varied dietary levels. The condition factor for this study was relatively higher than the values (0.65-0.70) documented by Anyanwu et al. (2007) for C. gariepinus fed at 3\% body weight as against 5\% body weight per day.

The increment in the higher $\mathrm{K}$ values might be due to feeding of the fishes to satiation and indicated that the fishes are in good health condition in the tanks. Deekae et al. (2010) recorded several reasons that may affect the condition factor of fish. They vary from fat accumulation, spawning, feeding and food nutrient composition.

The variations in condition factor (K) of fish according to King (1996) may be due to the abundance of food, how they adapt to their habitats, and the development of their gonads. The overall mean condition factor obtained in this study (0.848) varied slightly with results from other studies. Fafioye and Oluajo (2005) recorded mean condition factor of 0.79 for C.gariepinus in Epe lagoon and Anyanwu et al. (2007) recorded $\mathrm{K}$ of 0.654 for $C$. gariepinus reared in water recirculatory system. The values obtained in this study (0.58-1.06) revealed that the fishes were in good condition.

\section{CONCLuSION}

In conclusion, the optimum inclusion level of $O$. gratissimum to $C$. gariepinus diet is $10 \mathrm{~g} / \mathrm{kg}$ of feed for good growth. C. gariepinus fed $10 \mathrm{~g} / \mathrm{kg}$ inclusion of $O$. gratissimum leaf meal had the highest weight and length gain of $181.06+1.34 \mathrm{~g}$ and $31.51+0.56 \mathrm{~cm}$, highest values of feed conversion ratio of $9.05 \pm 0.07 \%$, the least values for condition factor(k) of 0.58 and highest value of $17.33 \pm 0.33 \%$ for survival rate. Therefore, it can be concluded that an inclusion of $10 \mathrm{~g} / \mathrm{kg}$ of $O$. gratissimum in the diet of $C$. gariepinus will yield optimum results.

\section{REFERENCES}

[1] Adegbeleye, W.O., Oresequn, A. and Ajitomi, O.O. (2001). An assessment of Jackbean (Canavalia ensiformis) meal as an ingredient in the diets for Clariasgariepinus (Buchell, 1822) fingerlings. Fish Nutrition and Feed Technology, ed. Eyo, A.A., FISON, pp. $92-97$.

[2] Anyanwu, D.C. (2008). Effects of some tropical plants leaf meals on the performance of Heteroclarias (H.bidorsalis x C. gariepinus). Ph.D Thesis, Fed. Uni. of Techno, Owerri, Imo State, Nigeria, $203 \mathrm{pp}+$ xvii.

[3] Akinyemi, K. O., Bayagbon, C., Oyefolu, A. O. B., Akinside, K. A, Omonigbeyin, E. A., Coker, A. O. (2000). Antibacterial screening of five indigenous Nigerian medicinal plants against S. typhiand S. paratyphi. Journal of Nigerian Infection Control Association 3(1):30-33.

[4] Association of Analytical Chemist AOAC (1990). Official methods of analysis $15^{\text {th }}$ edition.AOAC mc, Arlington, Virginia, USA, (Feed analysis).

[5] Erfanullah and Jafri, A.K. (1998). Growth response, feed utilization and nutrient retention in catlacatla (Ham.) fry fed varying levels of dietary carbohydrate. Asian fisheries science, 11:223 230.

[6] FAO.,(2003). Opportunities for aquaculture development in Nigeria, FAO Aquaculture Newsletter No 29. FAO, Rome, pp: 39.

[7] FAO, (2004).World Aquaculture supply of catfish and tilapia. FAO fisheries report No 733 FAO Rome, pp: 46.

[8] Ilori, M, Sheteolu, A. O., Omonigbehin, E. A., Adeneye, A. A. (1996). Antibacterial Activity of Ocimum gratissimum(Lamiaceae).J. Diarhoeal Dis. Res. 14: 283-285

[9] Junaid, S. A., Olabode, A. O., Onwuliri, F. C., Okwori, A. E. J., \& Agina, S. E. (2006).The antimicrobial properties of Ocimum gratissimum extracts on some selected bacterial gastrointestinal isolates. African Journal of Biotechnology, 5(22), 2315-2321.

[10] Lemos, J. A. and Paula, T. R. 2005. Anitfungal Activities of OcimumgrassitimumTowards DermatophytesJ. Ethnopharmocool 48(1): $72-86$.

[11] Ochang, S.N. Fagbenro, O.A. and Adebayo, O.T. (2007). Growth performance, body composition, /haematology and product quality of the African catfish (Clarias gariepinus) fed diets with palm oil. Pakistan Journal of Nutrition, 6(5): $452-459$. 
[12] Okigbo, R. N. and Igwe, M. 2007. The Antimicrobial Effects of Piper Guineenseuzizaand Phyllantusamarusebe-benizo on Candida albicansand Streptococcus FaecalisActa Microbiological et. Immonologica Hungarica 54(4): 353 - 366.

[13] Oladosu, G.A., O.A. Ayinla, A.A. Adeyemo, A.F. Yakubu and A.A. Ajani, (1993). A comparative study of the reproductive capacity of the African catfish species Heterobranchus bidorsalis Geoffroy, Clarias gariepinus Burchell and their Hybrid "Heteroclarias" NIOMR Technical Paper No. 92.

[14] Olvera-Novoa, M., Olivera-Castillo, L. and Martinez-Palacion, C. A.(2002)Sunflower Seed Meal as a Protein Source in Diets for Tilapia Rendalli(Boulanger, 1896) Fingerlings. Aquaculture Research, 33: 223-229.

[15] Oresegun, A. and Alegbeleye, W.O. (2001). Growth response and nutrient utilization of tilapia (Oreochromisniloticus) fed varying dietary levels of cassava peels based ration supplemented with D, L-methionine Fish Nutrition and Fish Feed Technology, FISON, pp. 36 - 45.

[16] Plail, R. (2006). ‘The Innovative Power of Probiotics', Poultry International.Pp. 34-36.

\section{AUTHORS' BIOGRAPHY}

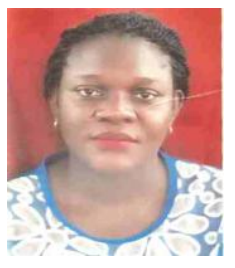

MARROH Eseoghene, holds a B. Fisheries degree from Delta State University, Abraka Nigeria. She is currently pursuing a Master of Science degree in fisheries from the same University.

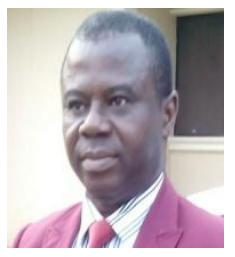

EKELEMU Jerimoth Kesena, holds a B.Sc, M.Sc and Ph.D degree in Fish Biology, Hydrobiology and Fisheries/Limnology respectively. He is currently an Associate Professor of Fisheries/Limnology in the Department of Fisheries/Aquaculture Technology in Delta State University, Abraka Nigeria. 